\title{
An Outline of the History of Gunpower and that of the Hand-Gun, from the Epoch of the Earliest Records to the End of the Fifteenth Century
}

\section{R. Coltman Clephan F.S.A}

To cite this article: R. Coltman Clephan F.S.A (1909) An Outline of the History of Gunpower and that of the Hand-Gun, from the Epoch of the Earliest Records to the End of the Fifteenth Century, Archaeological Journal, 66:1, 145-170, DOI: 10.1080/00665983.1909.10853113

To link to this article: http://dx.doi.org/10.1080/00665983.1909.10853113

Published online: 17 Jul 2014.

Submit your article to this journal $\sqsubset$

Џll Article views: 2

View related articles \lceil 
PLATE I.

To face page ${ }_{45}$.

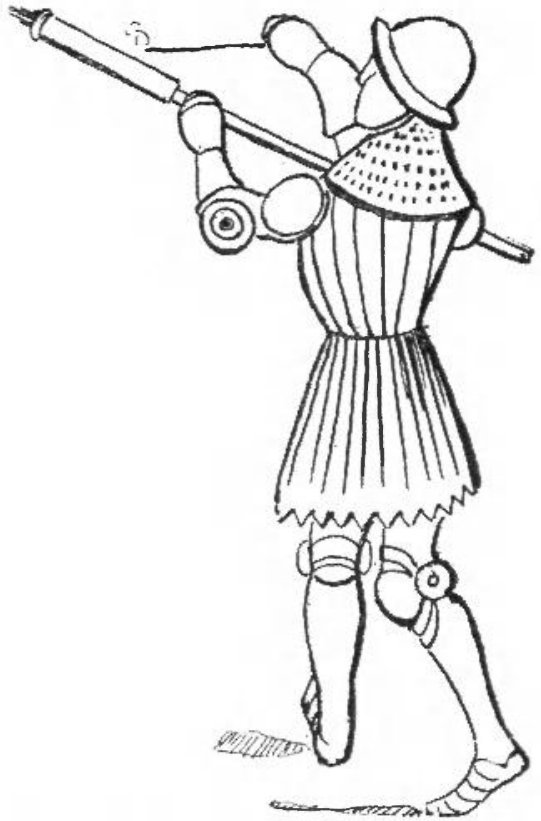

FIG I. FROM BUENEY MS. NO. I69, FOL. I27.

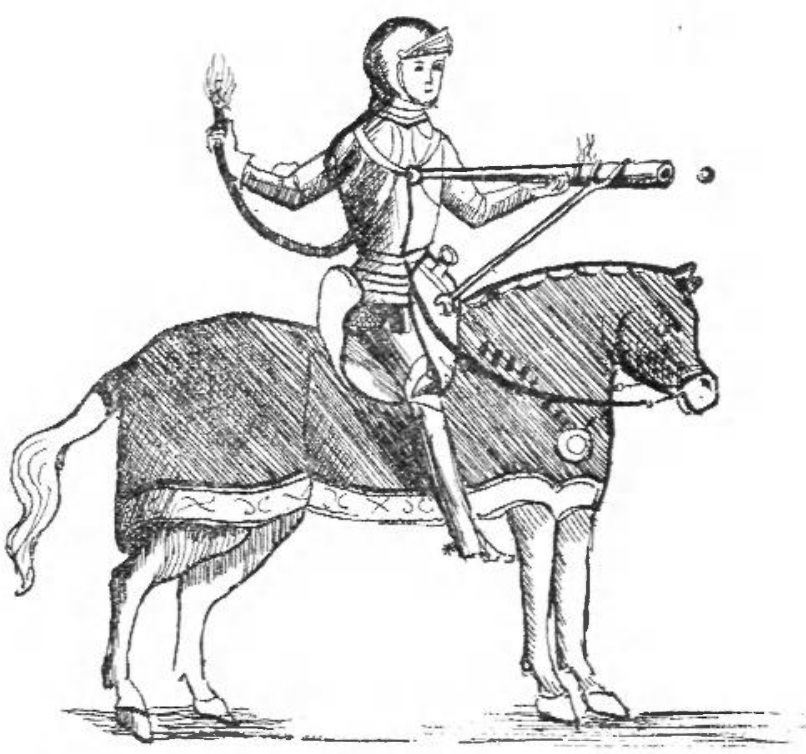

FIG. 2. ILLUSTRATION FROM MS. LAT. 7239 , in THE BIBLIOTHÉQUE RICHELIEU. 


\title{
AN OUTLINE OF THE HISTORY OF GUNPOWDER AND THAT OF THE HAND-GUN, FROM THE EPOCH OF THE EARLIEST RECORDS TO THE END OF THE FIFTEENTH CENTURY. ${ }^{1}$
}

\author{
By R. COLTMAN CLEPHAN, F.S.A.
}

THE early history of gunpowder and that of fire-arms in general is so interwoven that it is impossible to deal satisfactorily with the one without frequent reference to the other in the earlier stages of their development, and authentic sources of information on these subjects are so mixed up with spurious and doubtful ones, that both care and discrimination require to be exercised in the acceptance or rejection of many of the statements handed down from one writer to another, often without much examination or attempt at verification: the last word as to the approximate dating of certain of the manuscripts relating to these subjects often falling to the philologist or the palaeographist.

The chemists of early mediaeval times devoted much attention to the preparation of greek-fire, which was composed of live-sulphur, resin, oils, pitch, bituminous earths, oakum, salts, etc. The main purpose in its employment was to consume palisades, buildings within a fortification, or the formidable mechanical war-engines of their day. Vinegar, urine and sand were used to extinguish the conflagration it caused. There were many varieties of greek-fire, all highly inflammable and difficult to extinguish, and it wanted but the addition of saltpetre in a certain proportion to one or other of these compounds for conversion into a detonating powder; but when this admixture took place and in what country will probably never be known.

There can be little doubt that the earliest record we have of the mixture we call gunpowder is the Marcus 
Graecus MS, ${ }^{1}$ originally written in greek: and that the references to the explosive, made by Albertus Magnus ${ }^{2}$ (born I 193, died about I 280), the Spanish monk Ferrarius, ${ }^{3}$ and Roger Bacon ${ }^{4}$ (born I 2 I4, died about I292), were all taken directly or indirectly from this source. It is certain, however, that the year so long assigned to the record in question, A.D. 846 , was arrived at quite wrongfully, ${ }^{5}$ and that it is really much later, dating, in fact, probably early in the thirteenth century. Latin translations of the manuscript are possessed by the Bibliotheque Nationale at Paris, the Hof- und Staatsbibliothek at Munich, the Germanisches National Museum at Nuremberg, and, I am told, there is yet another copy at Oxford.

One of the Marcus recipes for ignis volans, i.e. gunpowder, runs as follows: " $\mathrm{R}$. lib. i sulphuris vivi, lib ii carbonis salicis, salis-petrose vi libras"; the mixture thus containing one part quick sulphur, two of charcoal of willow, and six of saltpetre, a stronger compound than any employed with fire-arms during the fourteenth and fifteenth centuries, and even later.

There is mention in a Chinese book on military matters, entitled $W$ upei-tschi, of a fiery mixture as having been employed in what would seem to have been bombs, at the siege of Pien-King, the present Kaifong, in I232, and Von Romocki gives a facsimile of the passage in his book $;^{6}$ not, however, taken from the original manuscript, which has been lost, but from a print of the Chinese work, published in I62I : and it is stated ${ }^{7}$ that there is a passage in Chinese annals of 1259 recording the use of a fiery powder in tubes of bamboo ; but such weapons, like the tubes of bronze described in the Alexiad by the Byzantine princess Anna Comnena, were not hand-guns as we understand the term, for they discharged no projectile, their purpose being merely of an incendiary nature. It

${ }^{1}$ Liber ignium ad comburendos bostes, which gives recipes for both greek-fire and gunpowder.

${ }^{2}$ Opus de mirabilibus mundi, an undated manuscript of the thirteenth century.

${ }^{3}$ The manuscript, an unedited epistle addressed to one Anselm, is in the Bodleian library, considered to be temp. Edward I.
4 Epistola de secretis operibus artis et naturae et de nullitate magiae. Anno 1257.

${ }^{5}$ By Hofer, in his Histoire de la Cbimie.

- Gescbicbte der Explosivestoffe. Published in 1895 .

'Zeitscbrift jur bistoriscbe Waffenkunde. B. iv, s. 66 . 
seems in every way probable that the Chinese first learnt the properties of gunpowder from Europe.

Coming now to the fourteenth century, the story of the invention of gunpowder by Bartholdus Niger (Berthold Schwartz), a monk of Freiburg in Breisgau, may be dismissed as being entirely legendary, and no more worthy of credence than the statement as to an entry which has been so often said to occur in the Memorieboek der Stad Gbant, under the year I3I3, the originator being a Professor Lenz, who made it in I840. The entry is said to run: "Item, in dit jaer var aldererst ghevonden in Duitschlandt het ghebruik der bussen van eenen mueninck," 1 but no such entry is present under that year. Mr. Oscar Guttman, in a description of an ancient cannon, printed in Kynocb's Journal, in I907, gives the copy of a letter written by a M. Diegerich, a Conservator of old records at Ghent, repudiating the story as to I3I3, though saying that an entry, similar in character, appears in a transcript of these annals, but under the year I393. The passage, however, is absent in the other five copies of the book that are known to exist; but even if that present in the one transcript be authentic, it has little or no significance as regards the history of fire-arms, for by that time (I393) ordnance had been in general use for more than half a century.

General Köhler, in Entwicklung des Kriegswesens, etc, ${ }^{2}$ refers to an ancient bronze hand-gun, once in the possession of the count d'Arco, which has the numerals $\mathbf{3} 22$ cut along it in bold characters. The weapon was stolen from the monastery of St. Orsola, at Mantua, in 1849. The count described it in 1847 and Angelucci in 1869. Standing above the numerals are the letters P P P F; and the weapon is ornamented with a greek cross and oak leaves. It is, of course, not quite certain that the numerals constitute a proof of date, but it is highly probable that they do.

There is another hand-gun preserved in Italy, of the first half of the fourteenth century, in the possession of Signor Gaetano de Minci, of Formo, a weapon stated to

\footnotetext{
1 In translation: "In this year (1313) the use of guns was first discorered in
}

Germany by a monk." Probably an interpolation based on the Schwartz legend.

2 Breslau, I 887 . 
have been dug up from among the ruins of the castle of Monte Vermine, in I84I.

At the beginning of the second quarter of the fourteenth century, on the last page, folio 69 , of a richly illuminated manuscript in the Christ Church library at Oxford, entitled De offciis regnum, by Walter de Millemete, bearing the date mcccxxvi, we find a vignette on which is represented a bottle-or flagon-shaped gun, ${ }^{\mathbf{1}}$ lying on a four-legged stand. A soldier, clad in a bascinet, a hauberk of chain-mail, a sleeveless surcote reaching down below the knees, and wearing quadrangular ailettes ensigned with a lion or a dragon, is standing by, and he is in the act of discharging the cannon, which is being directed against the gateway of a castle. Here, I think, we have the oldest pictorial representation of a piece of ordnance, with its missile, a bolt or garrot. ${ }^{2}$

In the following year, I Edward III, according to John Barbour, archdeacon of Aberdeen, ${ }^{\mathbf{3}}$ ordnance was employed in the campaign against the Scots. ${ }^{4}$

Fire-arms, in the sense of cannon, the word being synonymous with that of tubes, were in use in Italy in I324-1326, as shown by the well-known entry in the Archives of Florence, ${ }^{5}$ and in all probability for some time before.

John Anderne, a surgeon who lived early in the reign of Edward III, gives the following recipe for gunpowder in his curious treatise Practica: "Pour faire un fewe volant, Prenez i lib. de soufre vif, de charbones de Saux ij, de saltpetre vj lib," which is just the mixture of Marcus Graecus over again. ${ }^{6}$ There is very little information concerning early gunpowder, though it would appear that a very low grade was employed with ordnance at this period, probably because of the inherent weakness of the guns themselves, and this not owing to any deficiency in the tensile strength of the iron employed in their manufacture,

${ }^{1}$ A spheroid in form, with a long funnelshaped barrel.

2 These brass-feathered arrows or bolts, called carreaux, garrots, garrocks, etc, were freely used with the small ordnance and hand-guns of the period and later, as well as with the mechanical war-engine, the espringale.

${ }^{3}$ Metrical Life of Robert the Bruce.
* The statement is probable enough, though Barbour was only about seven years old in 1327 , so that he wrote from hearsay.

${ }_{5}^{5}$ Arcb. de Florence, reg. 23, De riformagioni, p. 65.

${ }^{6}$ Anderne describes greek-fire as "Fewes Gregois," and gunpowder as "Fewe volant." 
but rather lying in the imperfect welding together of the strips or bars of wrought iron, of which the weapons: were made; in fact, it would seem that the potency of the powder was mainly regulated by the ability of the ordnance to withstand the strain. ${ }^{1}$ The same remark applies to the hand-guns of this early period, though to a less extent than to ordnance, because of the greater relative power of resistance of the smaller weapons. I had an opportunity last year of closely examining two harquebusses of the larger sort, in the little arsenal in the castle of Schwarzburg, in Thuringia. They are of fifteenth century date, and the iron had been bent or rolled over a mandrel and welded; one of the guns, the smaller, being in a single plate, the other in two; the hinder ends blocked in when the iron was hot. The rule, however, was a single plate.

Peter Whitehorne in his book, Certaine $W$ ayes for the ordering of Souldiours in Battelray, etc, published in London in 1573 , states that the earliest gunpowder was made up. of equal parts of the three ingredients; while $\mathrm{Nye}_{\mathrm{e}}$, in his Treatise on Fireworks, says the same thing of that of the year 1380 ; but it is improbable that it ever contained less than two parts of saltpetre, for any smaller proportion in the dust-powder ${ }^{2}$ would hardly do more than roll a projectile out of the mouth of a piece. Nye gives the composition of I4IO as being three of saltpetre, and two. each of sulphur and charcoal; and we know from German sources that by the end of the fourteenth century or early in the fifteenth, the proportion of saltpetre in the powder had risen to three or four parts; and it is clear from the great size of some of the ordnance made, say, after I370, that by that time the process of welding had been much improved. An item in the king's wardrobe accounts, for the years $1372-1374$, gives 320 pounds of saltpetre and 107 pounds of sulphur in connexion with the service of certain guns, and this is practically three to one.

In Codex germ. 600, a manuscript in the Kongl. und

${ }^{1}$ Mons Meg, at Edinburgh, a cannon undoubtedly made at Mons about 1450 , shows a fracture, and the framework of the gun can be seen.

2 The ingredients of gunpowder were ground separately and first in mortars; there were, however, grinding mills in Germany as early as the first quarter of: the fifteenth century. The materials were carted about separately in leathern bags, and mixed together when wanted. 
Staatsbibliothek at Munich, dating, I should say, early in the fifteenth century, entitled Anleitung Schiesspulver $z u$ bereiten. Bucbsen $z u$ laden und $z u$ beschiessen, ${ }^{1}$ two kinds of gunpowder are mentioned. One, described as "schlecht"-the equivalent for the word being "bad" in the language of to-day, but then meaning "ordinary " 2 -made up of " 4 pfd. salniter, I pfd. schwefel und I pfd. kohle" ; the other, "Ein gut stark pulver," consists of the three main ingredients as in the "schlecht" grade, but with the addition of "I unze saltpetrie und I unze salarmoniak." The first recipe is clear enough, "salniter" being saltpetre ; but what is the "salpetrie" in the other ? May the distinction lie between the saltpetre made by the action of nitric acid on potassa and the natural incrustation $?^{3}$ The "salarmoniak" I take to be argol (Weinsteinsalz), the raw material from which tartaric acid and cream of tartar are prepared ; and we find urine sometimes added, while " quicksilver," salts of various kinds, alum, arsenic, camphor, amber, realgar, ${ }^{4}$ brandy and vinegar were thought to improve the mixture, distilled water of orange skins being employed for moistening it. Without knowing more as to the analyses of the saltpetres used in mediaeval times, the kind of wood employed for the charcoal ${ }^{5}$ and the quality and grinding of the sulphur, it is impossible to gauge the ballistic force of the compounds with any accuracy.

An entry occurs in the king's wardrobe accounts, under the year 1369, of "sea-cole" in connexion with parcels

\begin{abstract}
1 Directions for the preparation of gunpowder. How to load guns and bow to discbarge tbem. This important manuscript is dated by Wurdinger in $1345^{-1} 35^{\circ}$ (Kriegsgescbicbie von Bayern, Munich, I868), and by Max Jihn about the same time (Gescbicbte der Kriegswissenscbaften, Munich, 1889), while General Kohler dates it in 1377 (Entwicklung des Kriegswessens, etc, already mentioned), and Essenwein in 1390-1400 (Quellen zur Gescbicble der Feuerwaffen, Leipzig, 1877). The handwriting of the manuscript is very rough, such as might have been penned by a smith. The stage reached by the weapons delineated would point, I think, to a date in the first decade of the fifteenth .century, probably towards the end.
\end{abstract}

${ }^{2}$ An interesting example of the change of meaning undergone by a word over centuries. Had "bad" been meant, the German word "simpel" would have been used. In our own language the word "simple" has changed its meaning in a similar manner.

3 The natural incrustation, probably imported from Spain.

${ }^{4}$ Red sulphuret of arsenic.

- Marcus Graecus mentions willow, or alder, which were considered most suitable for gunpowder for ordnance; while that made with dogwood was preferred for hand-guns. Gunpowder with charcoal made from willow or alder is more violent in its action than that made with dogwood. (Robins, in a paper read before the Royal Society, in 1743). 
of sulphur and saltpetre, set aside for the service of certain guns; and another entry in these accounts for 1446 is of similar import, thus showing that coal-dust was sometimes used as a substitute for charcoal, but when this was done it is stated that a distillation of fish-paste was added.

More than one German manuscript reputed to be of the second half of the fourteenth century, though probably dating somewhat later, give instructions for loading firearms, directing that three-fifths of the barrel of a gun should be charged with powder, leaving the remaining two-fifths for the wad of spongy birchwood and the missile. The gunpowder of these early days being ground to a fine powder, the rate of combustion was slow, by reason of the smallness of the interstices between the grains through which the flames could pass along; thus, the cumulative force, so to speak, of the gas produced by the slowly burning dust, could not be brought to bear on the projectile, which was expelled from the barrel by only a portion of the energy the charge was capable of producing, and its velocity proportionately reduced; and owing to this slow rate of combustion, a good deal of the powder was blown out unignited. We learn from Codex germ. 6oo, the manuscript just referred to, that in order to obviate in some measure this waste of energy, a space was left between the rammed-down powder and the wooden wad or plug which separated it from the projectile, the object being to allow the gas first generated to accumulate in the hitherto vacant space. An old treatise on "Canonerie," of unknown date, printed in Paris in $156 \mathrm{I},{ }^{1}$ gives similar directions. But far more effective in this respect was the granulation of the powder, a process which originated as early as the close of the first quarter of the fifteenth century; and the fact is stated in the Feuerwerksbucb of Konrad Kauder, of Schongau, written in the year I429. It would seem, however, that the employment of granulated gunpowder had been abandoned for a season, the reason for which is unknown, and resumed again later: possibly its use at the earlier period was restricted mainly to hand-guns, more especially those of bronze, for we read of fine powder 
being employed with ordnance right through the fifteenth century. A Landshut record of the year 1430 states that each soldier with a hand-gun should carry a pound of powder, a pound of lead and a charge-measure; and in a Feuerwerksbuch of I454, in the arsenal library at Berlin, instructions are given for loading hand-guns; and there are drawings of the cylindrical vessels used to measure the charge. Thomas de Roldeston, keeper of the king's privy wardrobe, in which accounts all purchases of munitions of war were entered, bought gunpowder at eighteenpence per pound in $1347 ;^{1}$ while at Laon, in 1356 , it cost I 20 pence per pound; and accounts of the town of Caen, in I 375 , tell us that ten pounds of powder cost more than did " un grant canon," which, however, though relatively large, was really a small piece. In I 379 the keeper of the castle of Carisbrooke bought 100 pounds of saltpetre at fifteenpence, and 50 pounds of sulphur at sixpence per pound; while the price of gunpowder in Spain, where the natural incrustation was abundant, was only $3 \frac{1}{2} \mathrm{~d}$. and $4 \mathrm{~d}$. the pound in I5I2. These varying prices show that it was very much a question of local supply and demand.

The successful employment of gunpowder with ordnance, to effect by detonation what had been previously accomplished by an application of the forces of resilience, and of counterpoise, to such mechanical war-engines as the ballista, the mangonel, the espringale and the trebuchet, would be suggestive of its extension to hand-guns, to work with the longbow and the crossbow. We may perhaps either infer from the records at our disposal that the interval lying between the invention, or rather the general employment of ordnance, and the extension of the principle to hand weapons, was short. It is rarely possible to differentiate ordnance from hand-guns in the early texts relating to fire-arms, and more especially so in those of the second half of the fourteenth century, for the same nomenclature is often applied to both weapons. There is very little difference, if any, in the form and size of the very early pieces, the distinction between the two classes lying greatly in the fact that ordnance was discharged mounted on a rampart or a stationary block,

${ }^{1}$ M.M.XXI. lib. de saltpetra et CCCCLX.VI. lib. sulphur vivi. 
later placed on wheels, whilst the fire of the hand-gun, the small metal tube attached to a staff or stock, was delivered from against the person of a man with or without a portable rest. Take, for instance, the guns ordered by

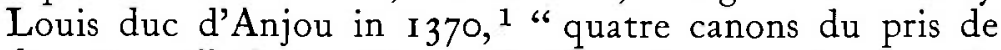
doze franx," thus costing only three francs apiece, surely these weapons were very small and probably hand-guns.

When terms occur in contemporary records, such as bandgunnis, bandgone, ${ }^{2}$ bandbücbsen, handbusen, fustbussen, quenons a main, bastons a feu, petites boucbes a feu, bombardes a main, canons a main, coulevrines à main, sclopos, scopitus, schioppi, scbiopetto, with the French equivalent in escopettes, coulevrines emmanchees and the harquebus proper, with the smaller piece balbebaken (English demi-hake), there can be no doubt as to the class of weapons meant. The terms hand-cannon, baquebutes à croc, doppelbaken (English double-hakes) and doppelte-doppelbaken, denote portable pieces, worked by two men, sometimes three, and discharged from a rest, stand, or rampart; and perhaps armes a feu portatives and bombardes portatives may be placed in the same category, while the term bücbsen, in early German records, may apply to either ordnance or hand-guns, but later it was used to express the latter alone. The Italian pieces mentioned, and the bantpücbsen and balbebaken, usually shot half-ounce to three-quarter-ounce balls, the bakenbuchse (English harquebus) threw one ounce, while the projectile for doppelhaken weighed two ounces. Two bantpüchsen are scheduled in a Vestenberg inventory of 1389 . After the invention of trunnions, which took place about the middle of the fifteenth century, some of the larger pieces were worked with these appliances, and may be more properly classed as small ordnance. Lotbucbsen derive their name from lot, lead, which refers to the bullet. They vary in size, but were all heavier than hand-guns, and all belong to the harquebus class.

"Un handgone" is mentioned in England as early as

\footnotetext{
1 Original manuscript among Les titres scelles de Clairambault, t. 46 .

2 The word "gone," "gonne" or gun would appear to have descended from the mechanical war-engine, the mangona or mangonal. Names were freely handed down from certain war-engines to others worked on quite different principles, a
}

circumstance often giving rise to diffculties in identification. The word "gonne" is used by Anderne in Practica, “ C'est poudre vault a gettere pelotes de fer ou de plom ou d'areyne, ove un instrument qu l'em appelle gonne." These bullets were thus of iron, lead or brass. 
the year $\mathbf{I} 33^{8}$, in an indenture between John Starlying, formerly clerk of the king's ships, and Helmying Leget, keeper of the same, dated 22nd June, I I Edward III; but a still earlier record of the weapon occurs in the Chronicles of Cividale, ${ }^{1}$ under the year I33I, running: "Ponentes vasa versus Civitatum. ...." "Et extrinseci balistabant cum scolpo versus Terram . . . et nihil nocuit ; ${ }^{2}$ and there is another Italian record in the Cbronicon Extense of 1334 , in which a sclopetus is mentioned. The city records of Perugia, of the year 1364, contain the oftquoted passage: "Il nostro comune de Perugia fece fare ... 500 bombarde una spanne lunghe, che le portavano su in mano, bellisime, e passavano ogni armatura"; thus 500 piece, each a span long, the usual length of the hand-guns of the second half of the fourteenth century. The record enjoins that the bullets for these pieces should pierce any harness, an expectation hardly likely to be realised. This is a very large number of handguns for a single arsenal at the period, and the only instance of the kind met with.

There is very little mention of hand-guns in English records before the Wars of the Roses, probably because of the great popularity of the long-bow in England; so we must look to other sources for information concerning these weapons.

Although Germany and Austria would seem to have been later in the field than Italy, the States of Flanders, France, Spain and England in the employment of fire-arms discharging projectiles, the number of examples of early ordnance and hand-guns in collections, both public and private, in the first-named countries, is much more considerable than in any of the others: and the amount of illuminated literature, dealing with an early period in the history of fire-arms, is proportionately large, so that it is greatly to the museums, the feuerwerksbücher, the gescbütz and zeugbücber ${ }^{3}$ of these countries that we must turn for examples both actual and in drawing.

Hand-guns are scheduled in a smith's account of Ratisbon, entered in Gemeiner Regensburger Cbronik, under IA town in the Venetian province of
Fruile.
'Muratori, in Rerum Ital. Scriptores, t. 18 , c. 176 .

${ }^{3}$ Zeugbiucber are the arsenal inventors 
the year I379. The entry runs: " II in Holz verrichette Büchsen, die zusammen 120 pund wiegen," that is, eleven hand-guns set into wooden stocks and weighing about eleven pounds apiece; and it is recorded under the year I381 that the council of the city of Augsburg had 30 hand-guns made for the defence of the town against an expected attack by the nobles of France (Franconia ?), Bavaria and Swabia. 1 Under the year I388, the following passage occurs in a Nuremberg record: "Bei jedem Sturm ro Handbüchsen;" while chronicles of the towns of Mohringen and Kaufbeuren, of the same year, contain clear mention of hand-guns. In an account of 1390 , a hand-gun is invoiced at "I I schilling Heller." Actual examples of these weapons of the fourteenth century are very rare; and but few hand-guns with the original shafting remain to us. In Quellen zur Geschichte der Feuerwaffen, a work already mentioned, Herr Essenwein has collected together a number of facsimiles of figures of hand-guns from illuminated miniatures, with copies of others from wood engravings and copperplates; and he gives drawings of original weapons and models, thus providing a fruitful store of information which has been largely drawn upon by all subsequent writers on the subject. There are also Beitrage zur Geschicbte der Handfeuerwaffen and Geschicbte der Handfeuerwaffen, by Captain J. Schö, ${ }^{2}$ and a series of valuable papers on hand-guns are published in the Zeitschrift fur bistorische $W$ affenkunde (Dresden) $;^{3}$ and to all these publications I have been continually and especially indebted when writing the present paper. There are other works of importance, containing references to gunpowder and fire-arms, many of which are mentioned in the course of these notes.

Contemporary records of France of the second half of the fourteenth century are especially rich in allusions to ordnance, but there is no mention, I believe, of handguns in the sense of weapons discharged from against the person, i.e. the cheek, chest or shoulder, without a portable rest, at this very early period of their history, or indeed

${ }_{1}$ Du passe et de l'avenir de l'artillerie, 6r.

${ }^{2}$ Tbierbacb Festscbrift, Dresden, 1905. The work by Captain Schon, Dresden, 1858 .

${ }^{3}$ The Society was founded in 1897 by the late Wendelin Bocheim, Max ron Ehrenthal, Schlosshauptmann von Cranach and others. 
over the one we are dealing with; the general trend of the records available would indicate that the French troops did not use hand-guns in this manner at all; their weapons being the heavier pieces, barquebutes $\dot{a}$ crock, supported upon rests, and light primitive petronels from horseback, like that shown on fig. 5 (described below), discharged from a short forked rest, attached to the saddlebow. The emperor Napoleon III, in Du Passe et de l'Avenir de l'Artillerie, ${ }^{1}$ says truly: "Les premiers canons dont l'histoire fasse mention étaient de si petit calibre, qu'on pourrait à la rigueur les considerer comme armes à feu portatives, si la grossièrete de leur construction ne les eut rendus difficiles à manier." He quotes Froissart : "En I 369, les Anglais, conduits par Jean Chandos, leverent devant Montsac aucuns canons qu'ils portoient," 2 and further states that the French had "bombardes portatives" in their campaign against Liege in $1382 .{ }^{3}$ Both these were probably hand-guns of the heavier sort, discharged from portable rests. There is an excellent collection of early fire-arms at Paris.

In Italy we have the case of Mantua of $\mathbf{1 3 2 2}$, and that of the castle of Monte Vermine of $134 \mathrm{I}$ or earlier; then the Cividale mention of hand-guns of I33I, the other of I334, and that of Perugia of 1364 ; and there are many reasons for the belief that the Italians were first in the field among the nations with fire-arms discharging projectiles, as they were with the making of harnesses of steel. The early bronze hand-guns in German collections are of good workmanship as compared with the roughness of those of wrought iron, believed to be of the same period, and the aspect of the former leads me to think that they may have been imported from Italy. We are confronted with a difficulty in this wide difference in the constructive efficiency and finish between these types, and if the very early bronze examples were made in Italy, which country was undoubtedly beforehand with Germany in the matter of fire-arms, as it was far in advance of it in bronze-work, it would go far to solve the problem. A century later the crude bronze-work of the early German craftsmen gave place

1 Paris, 1856 , P. 55 .

${ }^{3}$ Ibid.

'Ibid, 61 . 
to the splendid creations of the Vischer family of Nuremburg, whose foundry the emperor Maxmilian went frequently to visit. The work of this period exhibits the complete transition from the Gothic style to that of the Renaissance.

The museums of the Low Countries and of Switzerland furnish many examples of both early ordnance and handguns; and there is a considerable quantity of contemporary literature on the subject in both countries. The Netherlands probably come next after Italy in priority of time as makers of fire-arms. King Edward III drew his supplies of ordnance greatly, if not solely, through Ghent.

Scotland as well as England, and I believe Spain also, imported their fire-arms mainly from Flanders for at least two centuries. It would seem, however, that the Scots did not employ hand-guns at all before the middle of the sixteenth century, and then they had " of hakbutters but few or none." There are fine collections of ancient guns at Madrid and London.

It is impossible to date the manuscripts of the second half of the fourteenth and the first half of the next century to a decade or even in some cases considerably more, merely from the internal evidence they present; thus, there is no certainty as to whether figures in illuminations spring from the earlier or the later period: and there is usually the same uncertainty as regards actual specimens, the reputed dating of many of which may require reconsideration. Another difficulty lies in the often fanciful representations of fire-arms present in illuminations, some of them obviously drawn by artists with but little knowledge of the weapons they portrayed.

The earliest form of hand fire-arm was in all probability the sclopos, scolpos or scopitus. The hand-gun stolen from the monastery of St. Orsola, Mantua, is of bronze, I6 $4 \mathrm{~mm}$. long, with a weight of nearly $5 \mathrm{~kg}$. The other Italian specimen of the first half of the fourteenth century, that dug up from among the ruins of the castle of Monte Vermine, is much lighter, and of wrought iron. Further particulars of these hand-guns are given by Angelucci. ${ }^{1}$

The types of the second half of the fourteenth century, are firstly, a short, wrought iron, roughly finished tube, 
a span long, without chamber, the barrel ringed or otherwise strengthened at the muzzle, the touch-hole on the topmost side; secondly, a short, graduated tube of bronze or iron, with chamber, the touch-hole also on the uppermost side. The hinder ends of the tubes, after being blocked, were let into nearly straight wooden staves and secured to them mainly by hoops or rings of metal. Fig. I furnishes an example of what is probably of the firstnamed type, reproduced here from an illumination in Burney MS. No. I69, fol. I27. The soldier holds the piece in his left hand, at a considerable angle, the stock passed under the right armpit, whilst with the right hand he applies the burning match. The aiming capacity of a weapon so constructed and manipulated must have been of the slightest, and the recoil nothing worth mentioning. The other type, shown on fig. 3, is represented by an actual example, now in the museum at Nuremberg, an institution containing a remarkable collection of early

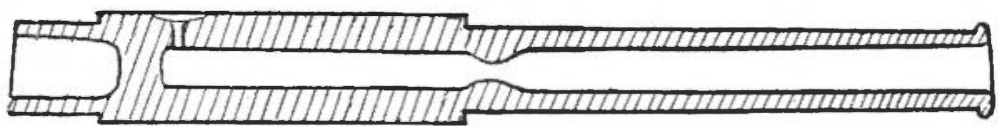

FIG. 3. THE TANNENBERG HAND-GUN.

hand-guns. The gun was dug up with several fragments of similar weapons in the year 1849 , when excavating the grass-grown ruins of Vesta Tannenberg, a robber stronghold in Hesse, taken by assault and dismantled in 1399 ; and here we have an undoubted example of a hand-gun of the second half of the fourteenth century. Part of the wooden staff was found with the bronze casting, but it fell to pieces on exposure to the air. An iron ramrod was also present. The casting is in three divisions, the hindermost portion for letting into the staff, the middle forming the chamber, and the third the barrel. The outer form is octagonal, the walls of the chamber thicker than those of the barrel, while the muzzle is strengthened by an outer thickening or ring. The touch-hole, placed in the uppermost side of the barrel, is $3 \mathrm{~mm}$. in diameter; it is bored perpendicularly, and there is a small, shallow, oblong extension along the barrel to afford sufficient space for the priming. The length of the casting is $0.33 \mathrm{~m}$, the calibre $35 \mathrm{~mm}$, and the weight is $1.235 \mathrm{kgs}$. This is 
a far more effective weapon than the other type, and some doubt as to the early date of the piece has been suggested by General Kohler, 1 based on the possibility that the fortress of Vesta Tannenberg might have been built up again after having been stormed in $\mathrm{I} 399$; but it has now been satisfactorily established that the place, blown to pieces then, was never rebuilt. It is rather common to speak of brass guns of this period, which is inaccurate. for the material was bronze.

Fig. 4 has an advantage over fig. $\mathbf{I}$, in that it represents an actual hand-gun, now in the museum at Linz, dating from about the end of the fourteenth or early in the fifteenth century. It is a wrought iron cylinder, round outwardly; the barrel $190 \mathrm{~mm}$. long, with a calibre of

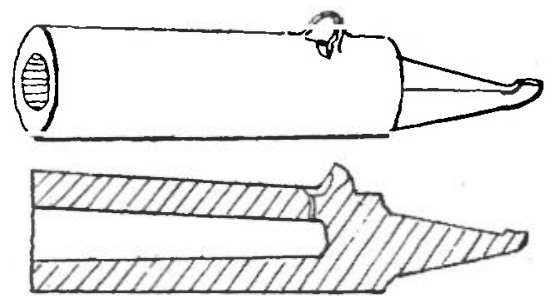

FIG. 4. HAND-GUN AT LINZ.

$32 \mathrm{~mm}$. The touch-hole is beaten out into a rough flash-pan, which is on the top side of the piece. ${ }^{2}$

From a very early period in their history some of these weapons were furnished with spurs, projecting from the underside of the piece, the use of which will be mentioned further on in these notes.

In some smaller pieces there is no depression around the touch-hole for the retention of the priming: the charge was probably exploded by some tinder stuck into the touch-hole and kindled for the discharge.

A valuable record of the transition period, that from towards the end of the fourteenth to early in the fifteenth century, exists in Codex MS. phil. 63 (Konrad Kyeser's Kriegsbuch Bellifortis, I396-I405), in the University library at Gottingen. As the fifteenth century advances, we are

\footnotetext{
1 Entwicklung des Kriegswesens, etc, of the barrel; later still provided with a written in 1887 .

2 The flash-pan was formed later as a hollow ledge, screwed on to the right side lid, moving on a pivot, to keep out the wet and prevent the priming from being blown away by the wind.
} 
able to trace notable improvements in these weapons; and a specimen in the museum at Nuremberg is attached to a stock which now begins to take definite form. A chamber becomes the rule, the barrel gradually lengthens, and the touch-hole and rough flash-pan are placed on the right side of the piece, the better to retain the priming; the last-named feature being first observed, I believe, in Codex 734, a manuscript in the Hof und Staatsbibliothek at Munich, dating from about 1460. There are many instances of the stocks being of iron in the first half of the fifteenth century. In Codex 719, a manuscript in the museum library at Nuremberg, dating from about the middle of the fifteenth century, the figure of a handgun is given, with the barrel one and a half times the length of the portion of the stock behind it. It is made stronger than hitherto, without increasing the calibre; the stock is better cut and more convenient to grasp, being trimmed to the hand and squared to the shoulder, while a long strip runs under and supports the barrel. The weapon is illustrated on fig. 5. These hand-guns are with-

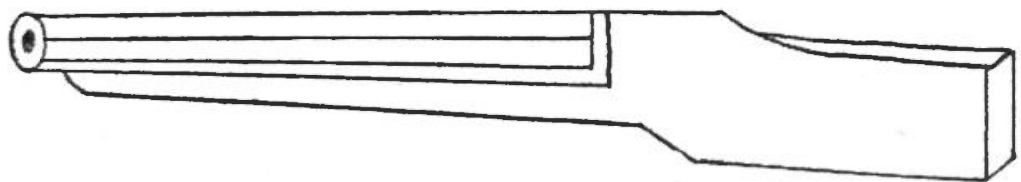

FIG. 5. HAND-GUN SKETCH IN CODEX 719 AT NUREMBERG.

out fixed sights, the marksmen sighting with their thumbs, as was done with the earlier crossbows; and it was first found possible to have a fixed sight placed on the barrel when the priming in the flash-pan became exploded through the agency of a mechanical contrivance. Still further improvements are illustrated in Codex pal. germ. I 30, a Landshut inventory of 1485 , now in the grand ducal library at Heidelberg, which exhibits the harquebus as fully developed in general form, though still without any mechanical appliance for discharge. These examples carry us over the middle of the fifteenth century, and may suffice to illustrate the leading types up to that date; after which the improvement becomes more rapid as the experience gained at the frequent shooting competitions of the day, together with practice in the field, made clear the weak points of the weapon. The barrel was drilled 
truer and the range extended. By about the period I460-I 480, many of the pieces were blocked with tailscrews, which besides being more reliable than the older method, had the advantages of more firmly fastening the iron portion of the piece into the stock, and afforded a ready means for a thorough periodical cleansing. As the weapon advanced towards some degree of efficiency, the question of meeting the difficulties incidental to the recoil occupied attention, and directions for holding the weapon are given in Codex 2952, a manuscript in the Hofbibliothek at Vienna, bearing the year of I457.

The English, French and Germans adopted the bent stock, while the Spaniards continued the straight form.

Hand-guns were not only used by foot soldiers, but from ribaudequins (military carts), the term inherited from the mechanical engine of the name. Drawings of these carts and their equipment are given in Codex 734, the manuscript at Munich, already quoted, and in the oldest undated edition of Vegetius, c. 1460-I470.

Small hand-guns were carried by horsemen as early as the first quarter of the fifteenth century; and the bodies of light horse so equipped developed in a later age into companies of Reiters and pistoliers. Victor Gay ${ }^{1}$ reproduces a mounted figure from MS. lat. $7239,{ }^{2}$ in the Bibliotheque Richelieu, which is copied here on fig. 2 ; it is dated by Bertholet about 1450 . The horseman, eques sclopettarius, is armed with a coulevrine $\dot{a}$ chevalet, that is a sclopos or schioppi; an esclopette (escopette), a primitive petronel, held at the present, and from which the bullet has just issued. The weapon is provided with a ring at the hinder end for stringing on to a leathern strap which encircles the horseman's neck, so that it can hang free when not being used. A short forked rest is attached by a ring to the saddle-bow, and this also hangs free after each discharge. One end of the long matchcord is fastened at the horseman's neck, and the soldier is still holding the burning end in his left hand, after having ignited the priming, all which arrangements made for mobility. The armour of the cavalier would fix the date near the end of the first half of the fifteenth century, 
corresponding, in fact, with that arrived at by Bertholet on other grounds. Such light hand-guns were also employed from mule-backs. The iron bullet used with them, later cased in lead in order to save wear and tear in the barrel, weighed about half an ounce. In the first quarter of the fifteenth century we find rore ${ }^{1}$ scheduled in inventories, which were for holding the burning match.

In a Breslau inventory of 1483 , referred to by Essenwein, ${ }^{2}$ a small hand-gun is scheduled as pischallen, and the word is rendered later petstoln; and here we have probably the origin of the word pistol. Such light weapons, discharged at arm's length and at close quarters, were usually termed fustroren and fustbussen in German records (faustrobren or faustbussen signifying fist-tubes or fist-guns). A drawing is given of an example in Codex germ. 734, a manuscript at Munich, dating from 1460 , which represents a horseman discharging the weapon at an opponent.

The harquebus (bakenbücbse, bakbut, arquebuze, arcbibuso, etc.) would appear to have owed its prefix bak, baken or barq to the spur of iron projecting from the bottom side of the piece, the function being to sustain the shock of the recoil by resting it against a wall or a portable forked rest of wood, shod with an iron spike, three or four inches long, to stick in the ground. The rests were of different lengths, according to the height of the men who used them. The suffix $a$ croc is the equivalent in the French language for bak or baken. The harquebus is a heavier piece than the handgone (bandbucbse, balbebaken or demibake, bandrobre, sclopos, etc.). The weapon is referred to by name in the year $\mathbf{1} 409$, in a town record of Brunswick; and, indeed, an even earlier instance has already been given. A very early example, complete with the ancient stock, may be seen at the museum at Berne. The touchhole, $5 \mathrm{~mm}$. in diameter, reaches slightly over to the right side; and it is not improbable that this feature and the bak or spur were later improvements, and also that the present stock may date from such a restoration. The spur fell into desuetude later, except in the case of the larger pieces. The larger varieties of the harquebus family, such as the harquebus à croc and the doppelbaken (English double-hakes), have been already referred to. Francesco

${ }^{1}$ High German, robre, tubes.

"Quellen, I I2. 
di Giorgi Martini, ${ }^{1}$ writing in $1460-1470$, states the length of the harquebus proper to be from three to four feet; and the missile a one ounce ball.

All these hand-guns were very inefficient, their handling was cumbersome, they were very short in range and without any precision of aim; and it is remarkable that, with so many drawbacks, they had made such headway as weapons of war. When worked by one man and fired from under the right armpit or against the cheek, breast or shoulder, the marksman had to apply the match with one hand, whilst holding the gun at the present with the other, so that any execution to be done in the ranks of an enemy must have been very slight indeed as compared with that wrought by the longbow or the cross-bow, the missiles from which were discharged at a flatter trajectory ${ }^{2}$ and a longer range, besides being more rapidly and precisely delivered. It is mainly owing to these causes that there is so little mention of hand-guns, as such, by mediaeval writers, more especially after the glamour caused by the superstitious terrors they inspired had more or less passed away. The number of soldiers killed by hand-guns in battle must have been insignificant; and as regards ordnance, De Comines, referring to the battle of Fournoue (1495), says : "L'artillerie des deux armées ne tua pas dix hommes."

The process of loading, discharging and cleaning off the slimy incrustation left by the dust-powder was very protracted; indeed it has been estimated that no more than six to seven shots could be delivered on the average per hour by each gun, while a good bowman with the longbow could discharge ten to twelve arrows a minute, and a crossbowman two to three quarrels in the same time: and attention was being directed at an early period in the history of hand fire-arms towards the achievement of a quicker succession of fire, and the principle of multibarrels, already being applied to ordnance, as shown in the Munich manuscript, Codex germ. 6oo, was soon extended to hand weapons ; but the gain was small, for it was found impossible to work such a hand-gun with a single soldier and yet have much chance of hitting a mark the size of a man.

1 Macbinarum liber.

${ }^{2}$ Compare the angle of elevation between the weapons figured on figs. I or 6 and that of 7 , for seeing what had been achieved in this respect from the commencement of the fifteenth century to its end. 
A Bologna inventory of 1397 schedules 4 scolpos pizolos in uno telerio. Drawings of some of these forms appear in Codex 10824, in the Hofbibliothek at Vienna; and an entry of canon polytubulaire occurs in an inventory of the Bastille of the year I435, which runs: "Unz canon a 7 troux, sans chambre, d'un espan de long ou environ," thus a repeating hand-gun with seven barrels, a span long or thereabouts. It will be noticed that this weapon is called a canon, a term applied, both in France and England, to the barrel of a hand-gun as well as to a piece of ordnance; and we owe our knowledge of its class solely to the fact of the length being mentioned. An actual example, with three barrels, weighing $3.770 \mathrm{kgs}$, may be seen in the museum at Nuremberg.

There were also attempts made to adopt the movablechamber system, already in operation with ordnance, to the smaller weapons, but the stouter construction necessary and the addition of a breech-block, of which there were several to each gun, made then unwieldy, the guns having a minimum weight of twenty-three pounds. Such weapons are figured in Codex lat. I390, in the University library at Erlangen, which dates from about I460-I480. Actual examples of breech-loading hand-guns may be seen in the museum at Nuremberg and at the Porte de Hal at Brussels.

Steps were also taken towards promoting a greater precision of aim, in devising means for obviating the most serious defect in the primitive form of hand-gun, the burning match for which was guided directly by one hand, the other holding the piece, and it was thus impossible for the soldier to keep his mark in view at the critical moment of firing. It was therefore most important to produce a workable mechanical appliance for bringing the burning match into a regular contact with the priming in the flash-pan; and of such inventions there are several varieties recorded, one, at least, going back very early in the fifteenth century. It would seem, however, that but a very small proportion ever got beyond the experimental stage, though some were perhaps used at target practice. The simplest of these inventions, the "serpentine," so named from its form bearing some resemblance to the tortuous movements of a snake, was manipulated directly by a finger, in such a manner as to enable the marksman 
to keep his eye on the object aimed at ; and this was the only one of these contrivances found to stand the rough usage of a campaign. The movement is more particularly described later. The Burgundians would seem to have used an appliance of this kind in warfare in $\mathbf{I} 43 \mathbf{I}$, for, indeed, the following entry in the national accounts of that year cannot well bear any other interpretation. The entry runs: "En I43I, il est payé a Pietre Donné canonier pour 25 couleuvrines... en baston, dont les deux d'icelles sont en façon d'une arbalaste, l'un à clef et l'autre sans clef."

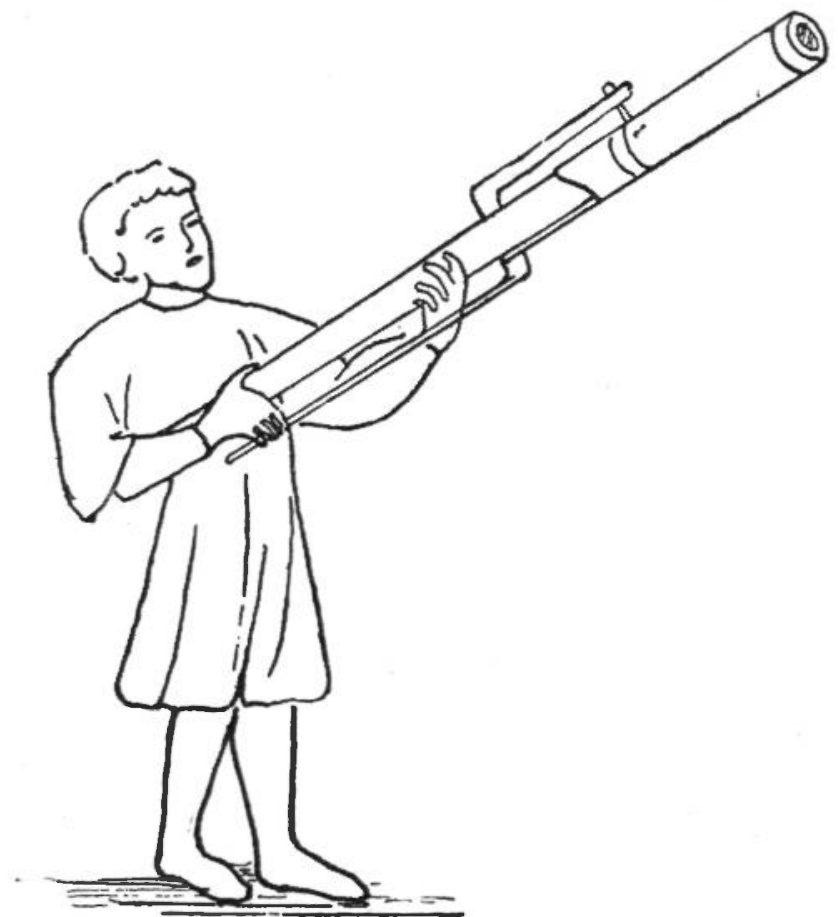

FIG. 6. FIGURE WITH HAND-GUN SHOWING EARLY LEVER MOVEMENT. FROM CODEX 3069, VIENNA.

There were early attempts made at a trigger, as might be suggested by the lock of the crossbow $;^{\mathbf{1}}$ and drawings

1 An early apparatus used with the crossbow was a trigger, working on a pivoting-pin, passed through the stock, and a pressure on the hinder end of the lever, towards the stock, brought the forward end sharply against a nicked nut holding the cord. This set the nut free, which, on revolving, released the string which had reposed in the notch, thus speeding the quarrel. This simple mechanism contributed much towards the formation of gunlocks, the most striking feature being the sear or trigger. 
of some of them appear in illuminations of the period. An example of one of these is given in a manuscript in the Hofbibliothek at Vienna, Codex $3069,{ }^{1}$ a record bearing the year of date 1411 , which is illustrated in fig. 6. The movement is a long, narrow iron rod, a lever of two arms or branches, working on a pivoting-pan, placed on the left side of the stock of the piece. It is bent twice almost at right angles, at a point about two-thirds of its length from the hinder end, thus forming the two arms, between which is the nearly rectangular portion of the bar or rod, through which the pivot runs. The lower arm forms a long trigger, then called a sear, whilst the upper arm of the lever extends along the top side of the gun. The lower arm or trigger is thus longer than the upper arm, and made so in order to lend the necessary leverage for bringing the match-end of the lever down on the pan. On a pressure with the fingers on the sear, towards the stock, the burning match, held in a pair of nippers at the end of the upper arm of the lever, is brought down into contact with the priming in the flash-pan. The sear is rounded while the rectangular and upper portions of the bar are flat. This invention anticipated the principle of the match-lock by many years, though in a very elementary and precarious fashion. Another curious form, working with a crank, is illustrated in Codex I390, the manuscript in the University library at Erlangen, already quoted from; and still another in Codex 55, a manuscript in the Kunsthistorische collection at Vienna, a record more than half a century earlier than no. 1390. None of these forms would seem to have been used in warfare. The "serpentine," employed in the field up to the end of the fifteenth century and for some time after, is a narrow iron rod or bar, bent somewhat semi-circularly or into a figure approaching the form of the letter $\mathrm{S}$ reversed, one end of which is pivoted to the right side of the stock of the piece; whilst the other end, fashioned like the head of a snake, holds the match-cord, adjusted in a position by a screw, in its mouth. A movement of the index finger of the soldier, when holding the weapon at the present, reverses or turns the bar on its pivot, bringing 
down the end holding the burning match into contact with the priming in the pan. There is thus neither sear nor spring. In this movement, placed either behind or before the flash-pan, we have the prototype of the cock. An example of this form occurs in Codex germ. 734, a record several times quoted from, which dates from about I460; and another, illustrated in Codex icon. 222, in the Munich library, reproduced on fig. 7 , represents a.

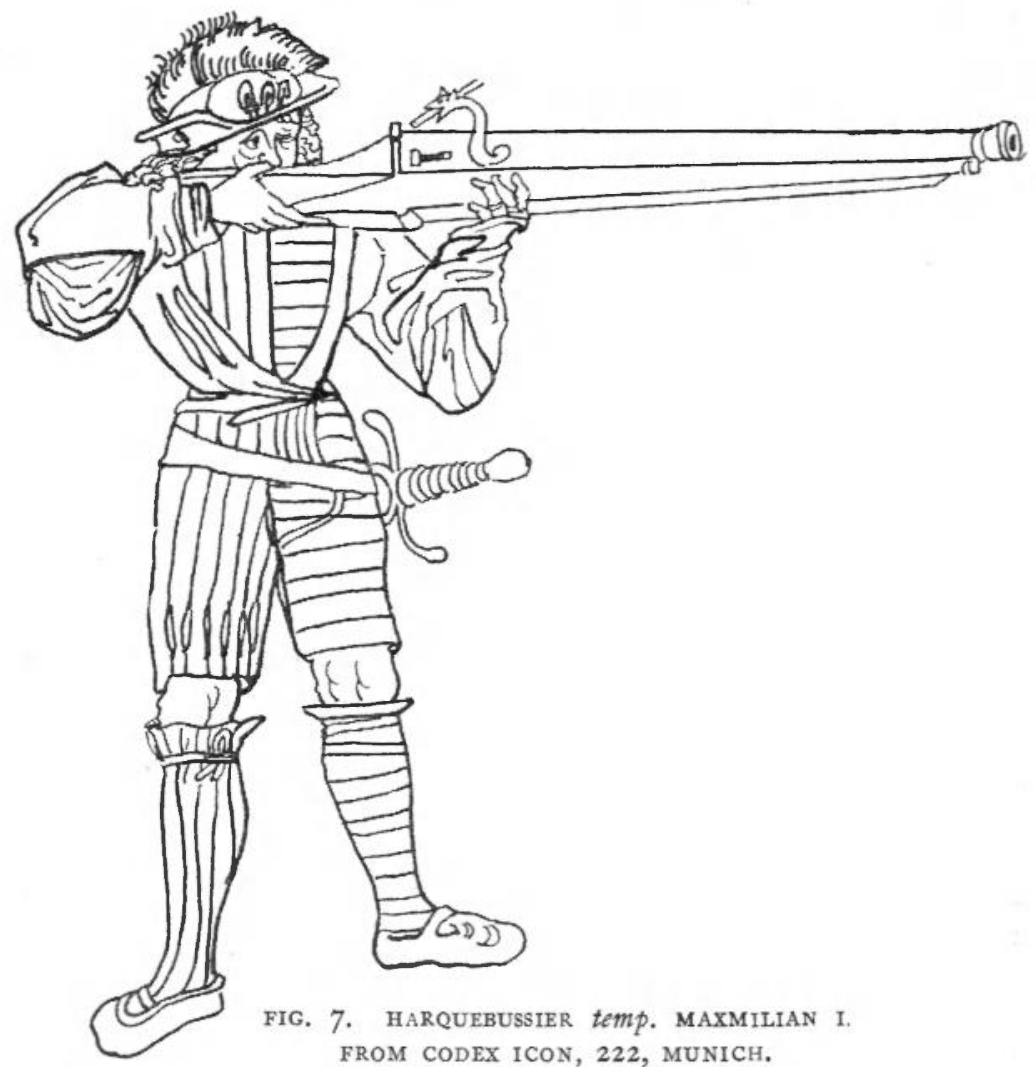

harquebussier of the reign of Maxmilian I, ${ }^{\mathbf{1}}$ clad in the fluffed and slashed contemporary costume, the landsknecbttracbt. The soldier is holding his weapon at the present; and here we have an example of the harquebus of the period. The bak or spur is gone, and the weapon is being discharged from against the shoulder: there is no, 
rest. There are many illustrations of this form present in the copious literature of Maxmilian's reign, concerning arms and armour. This simple contrivance continued so long in use in warfare mainly because it did not easily get out of order. The harquebus on fig. 7 is of a more advanced type than that carried by the Burgundian soldiers at the second battle of St. Albans, and which Philippe de Comines refers to as a new invention; and on comparing it to the bow, he remarks "la souveraine chose du monde pour les batailles sont les archers." Holinshed states that Edward IV, landing at Ravenspur, Yorkshire, in I47I, introduced hand-guns into England; and they certainly were carried by a contingent of Flemings, furnished by Charles the Bold, who fought in the battle under the Earl of Warwick. It was the harquebus with the "serpentine" that won victory for the Spaniards at the battle of Pavia. In 1467, Louis XI armed the Garde Civique with "le vouge la lance ou la coulevrine;" and when the yeomen of the guard were enrolled in England, in I485, one half was armed with the longbow and the other with the harquebus.

To judge from inventories very few hand-guns were stored in the arsenals of Europe up to the end of the fourteenth century; and in illuminations of the period one sees a single soldier with the weapon among a crowd of others bearing bills, bows, guisarmes, and the like; and indeed up to the middle of the next century the men armed with hand-guns were but very thinly spread among the infantry; but after that time the number of harquebussiers increases by leaps and bounds. A manuscript dating from about 1480-1490, in the Wolfegg collection, gives a sketch of a company of harquebussiers, numbering about forty men; and, indeed, by $1476-1477$, nearly a fourth of the infantry of Burgundy was armed with the weapon.

There is no reliable information that I can find as to the range of the hand-gun of the first half of the fifteenth century; but as to the second half, a Scbutzenbrief of Eichstadt, of the year 1487 , puts it at about two hundred yards. Codex MS. I 390, dated I 500, in the University library at Erlangen, gives examples of several forms of fixed sights. 
The match-lock was not employed in warfare before well into the sixteenth century; but that its evolution had reached an advanced, though still experimental, stage in the last quarter of the fifteenth century, or even earlier, is shown in Codex germ. 599, at Munich. This record bears the year of date I 475 , and is believed to have been written by Martin Merz, a celebrated director of fire-arms of his day, in which a hand-gun is illustrated with a gunlock having a lockplate, the wall against which the interior mechanism of the lock rested, but which hides it from view; and here a method of release by a series of small levers or, more likely, a system of spring and levers, must have been employed. The plate is attached to the stock by screws, and by the pressure of a finger on the now shortened sear, the cock falls in the direction of the muzzle and the burning match is brought into contact with the priming in the pan, here provided with a lid, moving on a pivot. There are breech and muzzle sights, and a needle for clearing out the touch-hole is attached to the stock, while a ramrod fits into a socket running along the bottom side of the piece. The drawing is reproduced on fig. 8. This

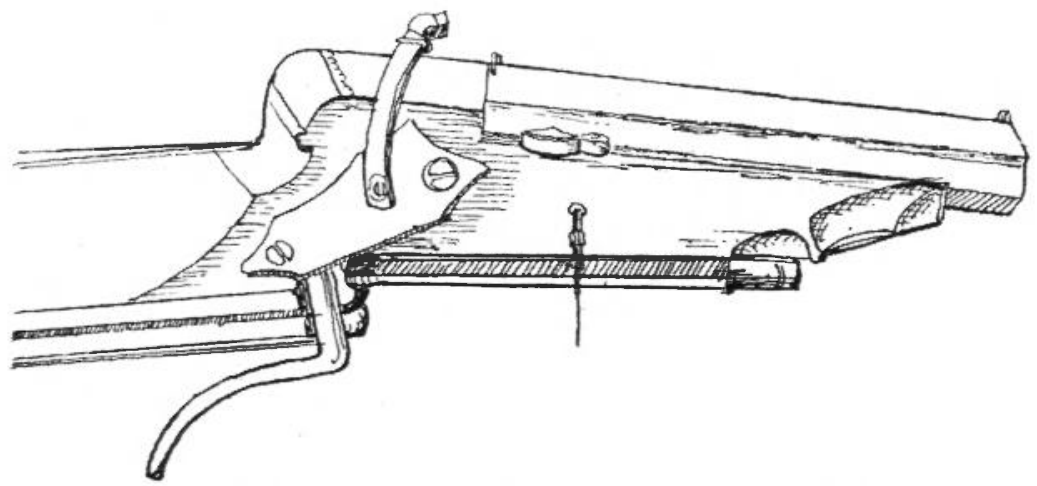

Fig. 8. hand-gun, Codex germ. 599, at munich.

is an early form of matchlock, a class of gunlock still in use at the end of the seventeenth century. This example presents yet another of those inventions in advance of their time, for we meet with nothing like it in warfare until long after, though it is quite possible that hand-guns with such a lock may have been used at target practice. 
The addition of the lockplate itself was a great step in advance, for the mechanism of the lock is built on to it, while in the case of the lock of the crossbow the internal fittings are pivoted in position by pins, running through the stock.

The process of rifling barrels, by cutting long straight grooves lengthwise, dates from the closing years of the fifteenth century, if not before; and the fact is stated in an account of a shooting competition (Scbeibenschiessen) held at Leipzig in $\mathbf{1 4 9 8}$, and the name of the inventor, Caspar Zollner, of Vienna, is mentioned. ${ }^{1}$ These parallel grooves would not, I imagine, lend any rotary motion to the projectile, and the idea of cutting them was probably conceived with a view of preventing the clogging of the weapon by the accumulated incrustation of the slimy residue left by the powder, the frequent clearing away of which had contributed so much to the extremely dilatory delivery of fire.

The general history of the hand-gun of the sixteenth century has still to be written, though the important section concerning gunlocks has been exhaustively treated in this Fournal by Viscount Dillon.

\footnotetext{
1899 .

${ }^{1}$ Die gescbichtlicbe Entwicklung des Handfeuerwaffen, Oberst von Thierbach. Dresden,
} 